\title{
Investigation of SARS-CoV-2 RNA in Milk Produced by Women with COVID-19 and Follow-Up of Their Infants: A Preliminary Study
}

\author{
TALAT KILIC ${ }^{1}$, Sebnem Kilic ${ }^{2}$, Nurcan Kirici Berber ${ }^{3}$, Ayten Gunduz ${ }^{4}$, and Yasemin \\ Ersoy $^{1}$ \\ ${ }^{1}$ Inonu University Faculty of Medicine \\ ${ }^{2}$ Education and Research Hospitals of Malatya, TURKEY \\ ${ }^{3}$ Affiliation not available \\ ${ }^{4}$ Education and Research Hospitals of Malatya
}

February 18, 2021

\begin{abstract}
Objectives: Studies have shown that severe acute respiratory syndrome coronavirus 2 (SARS-CoV-2) is primarily transmitted from person to person via airborne droplets. It is unclear whether it can be shed into human milk and transmitted to a child via breastfeeding. We investigated the presence of SARS-CoV-2 RNA in human milk samples of 15 mothers with coronavirus disease 19(COVID-19) and in the throat swab samples of their infants. Methods: This is a prospective observational study in which breast milk samples were collected from 15 mothers with COVID-19. The presence of SARS-CoV-2 RNA in the whole human milk samples of the patients was investigated using RT-qPCR. All of the infants underwent a clinical follow-up during their 14-day isolation and their throat swab samples were tested for SARS-CoV-2 RNA. Results: Of 15 mothers with COVID-19, SARS-CoV-2 RNA was detected in milk samples from 4 mothers. The throat swab samples from these mothers' infants were found to be positive for SARS-CoV-2 RNA. Three of the four mothers were breastfeeding. In addition, during the 14-day isolation, all but three of the mothers breastfed their infants. Of the 12 breastfed infants, while the test for SARS-CoV-2 RNA in throat swab samples was negative in six of the infants, the other six infants, who had mild COVID-19 symptoms, tested positive for SARS-CoV-2 RNA.Clinical outcomes of all mothers and infants were uneventful. Conclusion: To our knowledge, this is the first case series with the largest number of cases with SARS-CoV-2 RNA positivity in human milk samples of mothers with COVID-19. However, we believe that the benefits of breastfeeding may outweigh the risk of SARS-CoV-2 infection in infants
\end{abstract}

\section{Hosted file}

The Manuscript.pdf available at https://authorea.com/users/359377/articles/509629investigation-of-sars-cov-2-rna-in-milk-produced-by-women-with-covid-19-and-followup-of-their-infants-a-preliminary-study 


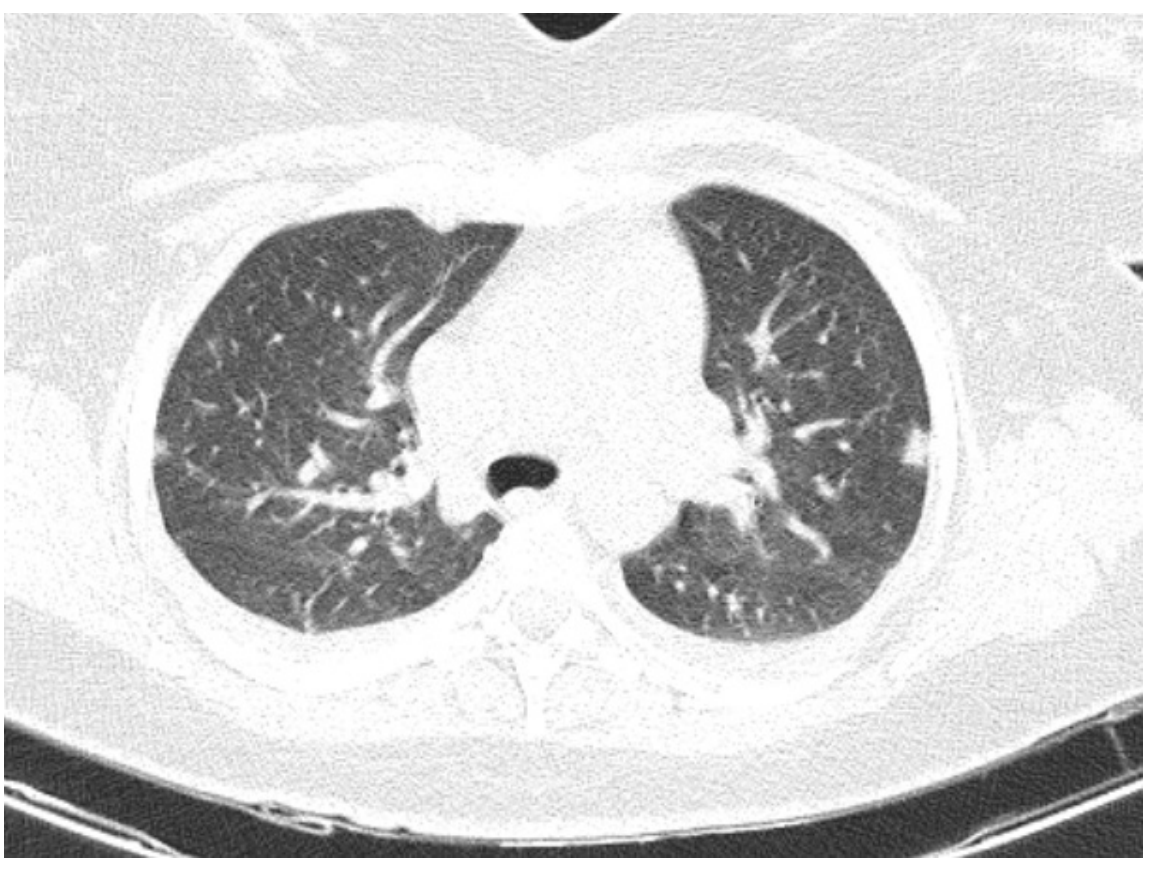

\section{Hosted file}

Table 1.pdf available at https://authorea.com/users/359377/articles/509629-investigation-ofsars-cov-2-rna-in-milk-produced-by-women-with-covid-19-and-follow-up-of-their-infantsa-preliminary-study 